Supplement of Atmos. Chem. Phys. Discuss., 14, 13731-13767, 2014

http://www.atmos-chem-phys-discuss.net/acpd-14-13731-2014/

doi:10.5194/acpd-14-13731-2014-supplement

(C) Author(s) 2014. CC Attribution 3.0 License.

(c) (i)

Supplement of

\title{
The effect of dry and wet deposition of condensable vapors on secondary organic aerosols concentrations over the continental US
}

C. Knote et al.

Correspondence to: A. Hodzic (alma@ucar.edu) 
Supplement of Atmos. Chem. Phys. Discuss., 14, 13731-13767, 2014

http://www.atmos-chem-phys-discuss.net/acpd-14-13731-2014/

doi:10.5194/acpd-14-13731-2014-supplement

(C) Author(s) 2014. CC Attribution 3.0 License.

(c) (i)

Supplement of

\section{The effect of dry and wet deposition of condensable vapors on secondary organic aerosols concentrations over the continental US}

C. Knote et al.

Correspondence to: A. Hodzic (alma@ucar.edu) 
Supplementary material for Knote et al., submitted ("The effect of dry and wet deposition of condensable vapors on secondary organic aerosols concentrations over the continental U.S.")

Table S1. SOA precursors and mapping to SAPRC species. Respective SOA mass yields are found in Table 1 in Lane et al. (2008b).

\begin{tabular}{l|l} 
MOZART species & SAPRC species \\
\hline BIGENE & OLE2 \\
\hline BIGALK & ALK5 \\
\hline TOLUENE & ARO1 \\
\hline BENZENE & ARO2 \\
\hline XYLENES & ARO2 \\
\hline ISOP & ISO \\
\hline APIN & TERP \\
\hline BPIN & TERP \\
\hline LIMON & TERP
\end{tabular}

